\section{Natureza, graça e cristianismo anônimo em Rahner*}

\section{Juliano Ribeiro Almeida ${ }^{a}$}

Faculdade Jesuíta de Filosofia e Teologia (FAJE) Brasil http://orcid.org/0000-0001-7491-2713
Resumo: Karl Rahner, ao articular natureza e graça em teologia sistemática, traz da escolástica para os desafios do nosso tempo o conceito de "cristãos anônimos”, que, depois de já se considerar superado por teólogos do diálogo inter-religioso de décadas atrás, volta ao cenário atual como relevante devido à nova onda de enrijecimento de alas conservadoras do catolicismo. Este artigo, refazendo o percurso trilhado por Rahner, investiga os sempre novos caminhos da graça divina, que deseja salvar a todos e todas, dentro e fora do mundo das religiôes.

Palavras-chave: Natureza; graça; diálogo interreligioso; ecumenismo; Karl Rahner; cristianismo anônimo.
Nature, Grace and Anonymous Christianity in Rahner

AвsTract: By taking from Scholasticism the subject of the relation between nature and grace, facing the challenges of our time, Karl Rahner forges the concept of "anonymous Christians". Such concept, which the theologians of inter-religious dialogue considered outdated decades ago, appears to be relevant nowadays, due to the strengthening of new conservative currents within Catholicism. This article follows Rahner's journey in order to address the ever renewed paths of divine grace, which seek to save all women and men, both inside and outside the world of religions.

KeY Words: Nature; Grace; Interreligious dialogue; Ecumenism; Karl Rahner; anonymous Christianity.

\section{CÓMO CITAR:}

Almeida, Juliano Ribeiro. "Natureza, graça e cristianismo anônimo em Rahner”. Theologica Xaveriana 188 (2019): 1-18. https://doi.org/10.11144/javeriana. $\underline{\text { tx69-188.ngcar }}$

\footnotetext{
* Artigo de reflexão
}

a Autor de correspondencia. Correio eletrônico: julianorial@gmail.com 


\section{Introdução}

Nos mesmos anos em que Karl Rahner escrevia os primeiros ensaios para sua obra Investigaçôes teológicas na Alemanha, um confrade seu jesuíta chamado Leonard Feeney enfrentava sérios problemas com a Santa Sé em Boston. Os dois filhos de Santo Inácio de Loyola trilhavam direçôes opostas em teologia. Rahner propunha a abertura da Igreja Católica ao mundo moderno, com uma conceituação mais ampla de graça, afirmando que também não-católicos e até mesmo não-cristãos podem alcançar a salvação e podem ser considerados "cristãos anônimos".

Do outro lado, Feeney insistia na interpretação literal e estrita da máxima de São Cipriano de Cartago Extra Ecclesiam nulla salus' ${ }^{1}$. Rahner, com sua teologia inovadora e progressista, foi um dos teólogos mais influentes no Concílio Vaticano II. Feeney, por sua vez, acabou sendo excomungado pelo Papa Pio XII em 1953 por causa de seu fundamentalismo e sua impertinência; no Boston College e no centro jesuíta de estudos na Harvard, ele ensinava que todos os que não forem batizados sacramentalmente na Igreja Católica romana não serão salvos. Portanto, de acordo com Feeney, judeus, muçulmanos, cristãos não-católicos e membros de quaisquer outras religiōes, bem como ateus e agnósticos seriam todos certamente condenados.

A nota de rodapé suplementar 19 do Capítulo II da constituição Lumen gentium 16, do Vaticano II, faz referência à carta que o Santo Ofício enviou ao arcebispo de Boston, cardeal Richard Cushing, em agosto de 1949, sobre a polêmica envolvendo padre Feeney. Na carta, o cardeal Marchetti-Servaggiani, prefeito do Santo Ofício, esclarece:

Para uma pessoa obter a salvação, náo é sempre exigido que ela seja de fato incorporada na Igreja como seu membro, mas que pelo menos se una à Igreja através do desejo ou da esperança. Porém, não é sempre necessário que esta esperança seja explícita, como no caso dos catecúmenos. Quando alguém está em estado de invencível ignorância, Deus aceita um desejo implícito, assim chamado por estar implícito na boa disposição da alma, pela qual ela deseja conformar sua vontade à vontade de Deus. ${ }^{2}$

Neste artigo, eu considero esse desejo implícito de pertencer à Igreja, que é necessário para a salvaçáo, como sendo, na verdade, o que Karl Rahner chamou de correspondência à graça intrínseca que Deus concede a todos os seres humanos, sem exceção.

\footnotetext{
1 "Fora da Igreja não há salvação". Na verdade, Cipriano diz "quia salus extra Ecclesiam non est" - "pois salvação fora da Igreja náo existe" (Epistola São Cypriani ad Jubaianum, Cap. 21, PL 3, 1123).

${ }^{2}$ Denzinger e Hünermann, Compêndio dos símbolos, definiçōes e declaraçôes de fé e moral, 3869-3872.
} 


\section{Natureza pura e gratuidade de Deus}

No período imediatamente anterior ao Concílio Vaticano II, estava em pleno desenvolvimento na Europa a discussão teológica sobre a relação entre natureza humana e graça divina. A partir da diferenciação clássica que a escolástica fazia entre "graça incriada" (que é o próprio Deus dando-se a si mesmo aos seres humanos ${ }^{3}$ ) e "graça criada” (justificação, graça santificante, virtudes teologais, dons do Espírito Santo, divinização do ser humano etc.), Rahner retoma a teologia postridentina e neoescolástica, segundo a qual a graça é "uma superestrutura além do âmbito da consciência”"

Natureza e graça parecem ser, então, duas realidades que se tocam o mínimo possível; a graça é o que aperfeiçoa a natureza, fazendo com que ela seja tão somente potentia obedientialis', "não mais que não-repugnância a tal elevaçáo"'. Assim, sem a graça divina, haveria no ser humano apenas "natureza pura".

Henry de Lubac, em seu livro Surnaturel (1946), retomando a ideia agostiniana e tomista, defendia que todos os seres humanos, "por natureza", são orientados para Deus. E esse desejo da visão beatífica já é efeito da graça incriada. Portanto, segundo de Lubac, não é possível sequer imaginar a natureza humana sem a graça; o conceito de natureza pura seria "uma possibilidade abstrata, uma heurística [i.e., um artifício] para salvaguardar a liberdade"

Rahner, apesar de concordar com a intenção de de Lubac de superar o extrinsecismo do conceito tradicional de graça, discordava da afirmação da nouvelle théologie de que essa orientação para Deus está no ser humano "por natureza”. Para Rahner, o desejo de Deus não faz parte da essência humana, mas é causada por Deus na existência humana, embora antes do aparecimento da liberdade pessoal.

Rahner pensa que a noção de natureza pura e sem a graça é necessária para entender o conceito de essência humana, anterior à sua concreta existência. Sem tal conceito, a graça seria uma contradição terminológica, pois não seria oferecida "gratuitamente"

\footnotetext{
3 "A graça é Deus mesmo, a comunicação na qual Deus se dá ao ser humano como um favor divinizador que é Deus mesmo. Assim, a obra de Deus é realmente o próprio Deus, já que Deus é o comunicado. Tal graça, desde o começo, não se pode pensá-la independentemente do amor pessoal de Deus e sua resposta no ser humano. Não se deve considerar esta graça uma 'coisa'. É algo apenas posto à disposiçáo do ser humano naquele ato de 'deixar alguém dispor' daquilo que é o dom próprio da graça mais livre, o milagre do amor" (Rahner, "Nature and Grace" 4, 177).

${ }^{4}$ Ibid., 4, 166.

${ }^{5}$ Potência obediencial é a capacidade de autotranscendência que está presente na pessoa já antes de Deus conceder-lhe a graça; é a possibilidade ou abertura inata que o ser humano tem de receber a graça, em virtude de ser criado "à imagem e semelhança de Deus".

${ }^{6}$ Rahner, "Nature and Grace" 4, 167.

${ }^{7}$ Duffy, "Experience of Grace”, 50.
} 
por Deus, e seria acolhida necessária e automaticamente pelo ser humano, ainda que inconscientemente ou "atematicamente", no dizer rahneriano. Além disso, Rahner lembra a repreensão do papa Pio XII aos teólogos que "destroem a gratuidade da ordem sobrenatural, já que Deus, dizem eles, não pode criar seres intelectuais sem ordená-los e vocacioná-los à visão beatífica"s.

É, portanto, necessário considerar a possibilidade de uma natureza sem a graça, no nível da essência, embora isso não seja possível no nível da existência concreta. "De fato, ainda que 'eu' tenha um fim sobrenatural, se Deus náo houvesse 'me' dado esse fim, 'eu' ainda existiria, embora com um fim puramente natural"'. A graça é, portanto, intrínseca à natureza, pois já no ato de criar o ser humano, Deus se dá a ele como graça incriada, como condição de possibilidade da transcendência humana, embora tal graça não se identifique com a natureza.

Natureza e graça são duas realidades distintas; e se cairia no erro panteísta se se afirmasse a graça como sendo "parte" da natureza, fazendo com que Deus entrasse na composição do ser humano, o que seria um absurdo. Segundo Rahner, "a graça é dada antes de uma decisão existencial, como uma 'oferta' e uma 'possibilidade' (de um livre ato salutar)" ${ }^{10}$. Para Rahner, essa autodoaçáa de Deus ao ser humano como graça incriada não é adicionada à natureza posteriormente à criação, nem é condicionada por disposiçôes humanas, tais como atitudes morais ou afiliaçâo religiosa, e nem mesmo é consequência da aceitação da graça criada ou seu efeito.

A graça incriada é a própria inabitação de Deus na pessoa humana, primeiramente por esta ser uma criatura que tem o ser sustentado por Deus, e em segundo lugar por ser criado à imagem e semelhança, independentemente de quaisquer circunstâncias. Isso garante que a graça seja de fato totalmente gratuita. Se assim não fosse, ela seria, de alguma forma, recompensa de Deus a uma disposição da vontade humana. Além disso, "a visão beatífica só é para mim gratuita se eu puder não tê-la como meu fim" "11, isto é, se for puro dom de Deus para mim, dependente da minha livre aceitação e não uma determinação ou condição inevitável da minha natureza.

\section{O plano divino da salvação universal}

O conceito de graça para Rahner está diretamente ligado à ideia da vontade divina de salvação universal. De fato, como diz o apóstolo Paulo, Deus nosso Salvador "deseja

\footnotetext{
${ }^{8}$ Pio XII, "Carta encíclica Humani generis", 26.

9 Coffey, “The Whole Rahner on the Supernatural Existential”, 100.

${ }^{10}$ Rahner, "Nature and Grace" 4, 180.

${ }^{11}$ Coffey, "The whole Rahner on the supernatural existential”, 100.
} 
que todos se salvem e cheguem ao conhecimento da verdade" (1Tm 2,4). Para que isso aconteça, Deus se dá ao ser humano como graça incriada, que o torna "apto a receber esse amor que é o próprio Deus"12.

Essa graça é concedida universalmente e é antecedente à liberdade dos seres humanos, sendo, por isso, chamada de existencial sobrenatural. Este termo foi cunhado por Rahner para definir graça. A palavra existencial aqui é um substantivo, e sobrenatural, um adjetivo, conceitos que garantem a ideia de que a graça não é da ordem do essencial e nem se identifica com o natural. "A graça é sobrenatural porque indevida ao sujeito, mas isto não significa que seja uma realidade a ele extrínseca: é um existencial, ainda que de ordem sobrenatural"13.

A autocomunicação de Deus ao ser humano, "na qual Deus se torna ele próprio como que princípio constitutivo do ente criado, sem com isto perder sua absoluta independência ontológica, acarreta efeitos 'divinizantes' no ente finito que recebe esta comunicação" ${ }^{14}$. Rahner, em Curso fundamental da fé, afirma que Deus se dá ao ser humano como causa formal ${ }^{15}$, de acordo com o vocabulário aristotélico-tomista, isto é, como aquilo que possibilita o ser humano ser o que é.

Deus "não causa nem produz originariamente na criatura algo de diverso dele mesmo, mas antes, ao comunicar sua própria realidade divina, faz-se constitutivo da realização consumada da criatura" ${ }^{16}$, sem deixar de ser mistério absoluto e sem que o ser humano deixe de ser distinto de Deus. Para Rahner, é importante ressaltar que esta autodoação de Deus é que torna possível a aceitaçáo por parte do ser humano. Por isso, quando Deus pede, na Lei de Moisés, o amor humano a ele "com todo o teu coração, com toda a tua alma e com toda a tua força”" (Dt 6,5), isso não significa uma imposição divina que ordena que haja amor como resposta humana, mas quer dizer que o ser humano simplesmente deve "tornar-se aquilo que é", como escreveu o poeta grego Píndaro.

Esta concessão da graça incriada não pode ser confundida com a salvação ou a graça da justificação da pessoa. Se assim fosse, estaríamos falando de apokatástasis, isto é, uma espécie de restauração universal automática. Rahner explica:

\footnotetext{
${ }^{12}$ Rahner, "Concerning the Relationship between Nature and Grace” 1, 311.

${ }^{13}$ Teixeira, "Karl Rahner e as religiōes", 246.

${ }^{14}$ Rahner, Curso fundamental da fé, 150.

${ }^{15}$ No primeiro volume de Investigaçōes Teológicas, bem anterior ao Curso fundamental da fé, Rahner prefere falar em causalidade quase formal (cf. Th.I., v. 1, 330-331).

${ }^{16}$ Rahner, Curso fundamental da fé. Introdução ao conceito de cristianismo, 151.
} 
A transcendência sobrenatural está sempre presente em todo ser humano que tenha alcançado a idade da razão moral. Isso não significa necessariamente que ele esteja justificado. Ele pode ser um pecador ou um descrente. Mas onde e à medida que ele tenha a possibilidade concreta de um ato moralmente bom, ele está de fato constantemente dentro do horizonte de transcendência aberto a Deus e à vida sobrenatural. ${ }^{17}$

Toda a teologia de Rahner parece depender desses dois conceitos: "condição de possibilidade" e "horizonte de transcendência". Deus, com a graça sobrenatural, dá ao ser humano todo o necessário para a salvação, operando nele o querer e o agir, segundo a sua vontade $(\mathrm{Fl} 2,13)$. Se o ser humano recebe a graça que o faz desejar Deus e, ao mesmo tempo, o torna capaz de Deus, o objetivo da graça é que o ser humano finalmente veja a Deus face a face eternamente. A visão beatífica não é o prêmio reservado por Deus somente para aqueles que conseguirem cumprir suas exigências, mas é a consequência desta atuação universal da graça na própria constituição humana.

$\mathrm{Na}$ alegoria do julgamento final do Capítulo 25 do Evangelho segundo Mateus, Jesus diz que, no fim, “o rei dirá aos que estiverem à sua direita: 'Vinde, benditos de meu Pai, recebei por herança o Reino preparado para vós desde a fundação do mundo"” (v. 34) e "em seguida, dirá aos que estiverem à sua esquerda: 'Apartai-vos de mim, malditos, para o fogo eterno preparado para o diabo e para os seus anjos"' (v. 41).

Jesus afirma, assim, que todos os seres humanos são predestinados à visão beatífica, enquanto o inferno só é preparado para o diabo. Rahner explica que graça e visão beatífica "não passam de o anverso e o reverso de um só e mesmo evento, suas duas fases, condicionadas pela livre historicidade e temporalidade do ser humano. Não passam de duas fases interligadas e sucessivas da única autocomunicação de Deus aos seres humanos" ${ }^{18}$.

\section{A resposta atemática}

A nouvelle théologie já afirmava, como Tomás de Aquino, que a graça sobrenatural pode ser experimentada pelo ser humano na história, já que ela, apesar de não ser adicionada como uma outra camada sobre a natureza, passa a integrá-la. Rahner, porém, propóe um outro entendimento dessa experiência da graça:

.... graça sobrenatural constitui um objeto formal para o intelecto e a vontade humana, um horizonte que é a precondição para o conhecimento de qualquer

\footnotetext{
${ }^{17}$ Rahner, "Nature and Grace" 4, 180.

${ }^{18}$ Rahner, Curso fundamental da fé. Introdução ao conceito de cristianismo, 147.
} 
objeto particular do entendimento humano. Este objeto formal é um a priori que condiciona todo o conhecimento e a liberdade humana. ${ }^{19}$

Rahner explica que a experiência da graça sobrenatural é, na verdade, o exercício da capacidade humana da transcendência, mas no sentido mais amplo do termo. Tratase de uma experiência verdadeiramente espiritual. Porém, o "espiritual", "sobrenatural" e "transcendental" não têm, para Rahner, caráter exclusivamente religioso. A experiência da graça, portanto, não se limita ao âmbito da oraçáo ou da vida sacramental no interior da religião cristâ, onde a resposta a esta graça é temática, isto é, tematicamente consciente de estar diante da revelação de Deus na história.

A experiência da graça é táo ampla quanto a capacidade humana de construir pensamento, cultura, arte, moral etc. Os seres humanos podem "fazer esta experiência indiretamente ou atematicamente, quando experienciam o mundo" ${ }^{20}$. De acordo com Rahner, isso não acontece de forma "inconsciente" no sentido freudiano, mas apenas "atematicamente consciente", ou seja, indiretamente consciente. Além disso, ele ressalta:

Que cada um de nós procure a experiência da graça na contemplação da nossa vida, mas não de modo a que possamos dizer: aqui está ela; eu a possuo. Não se pode "encontrá-la" de modo a se afirmar triunfalmente que ela seja propriedade privada de alguém. Apenas se pode procurá-la ao se esquecer a si mesmo; apenas se pode achá-la ao se buscar a Deus e ao dar-se a si mesmo a ele no amor que se esquece a si mesmo, e sem voltar-se para si mesmo. ${ }^{21}$

Experimentar a graça incriada não é algo que esteja no nível do "sentir", pois está fora do alcance das emoçóes humanas. Experimenta-se a graça quando se experimenta a transcendentalidade da condiçáo humana. Como essa autocomunicação de Deus é um existencial sobrenatural e é tão ampla que o ser humano não consegue distinguir como sendo diferente do próprio horizonte da realidade em que vive, a resposta humana a ela é fundamentalmente atemática. "Encontramo-nos radicalmente em toda parte com Deus como questão dirigida à nossa liberdade, encontramo-nos com ele de maneira implícita, atemática, não-objetivada e não-expressa em todas as coisas do mundo" 22 .

Por isso, a resposta à graça não é idêntica à profissão de fé, mas é uma resposta mais profunda, que envolve a vida toda, de forma definitiva e não pontual ou momen-

\footnotetext{
${ }^{19}$ Wandinger, "Karl Rahner on Nature and Grace. A Journey through His Early Articles".

${ }^{20}$ Ibid.

${ }^{21}$ Rahner, "Reflections on the Experience of Grace" 3, 89.

${ }^{22}$ Rahner, Curso fundamental da fé. Introdução ao conceito de cristianismo, 124.
} 
tânea. Embora Rahner não explicite tal analogia, pode-se identificar essa experiência atemática da graça incriada e essa abertura transcendental à graça criada no ser humano com o que o magistério eclesiástico chama de "desejo implícito de pertencer à Igreja”, suficiente para a salvação.

O ser humano responde com sua liberdade à autocomunicação de Deus. Apesar de sempre haver a possibilidade de alguém rejeitar essa graça, voltando-se contra ela (o que seria o próprio inferno), "uma recusa a esta oferta [...] levaria o ser humano à contradição consigo mesmo no âmbito do seu próprio ser" ${ }^{23}$. Para Rahner, a liberdade não é a mera possibilidade de escolha entre um "sim" e um "náo" temáticos a Deus. Jesus mesmo disse: "Nem todo aquele que me diz 'Senhor, Senhor' entrará no Reino dos céus, mas sim aquele que pratica a vontade de meu Pai que está nos céus" (Mt 7,21). Assim, é possível que alguém dê um "sim" tematicamente a Deus, numa profissão formal da fé cristã, mas atematicamente esteja lhe dando um "não" na opção fundamental da própria vida.

Talvez a parábola dos dois filhos, em Mateus 21,28-31, possa ser interpretada também nesse contexto: o filho que diz "sim" à ordem do pai para ir trabalhar na vinha e depois acaba não indo representa os que dão uma resposta tematicamente positiva a Deus, mas atematicamente negativa. Por outro lado, o filho que disse "não", mas acabou indo trabalhar, pode representar as pessoas que, apesar de não reconhecerem objetivamente ao Deus de Jesus Cristo, respondem um "sim" atemático a este mesmo Deus se levarem uma vida correspondente ao Seu projeto.

\section{Cristãos anônimos}

Se a vontade de Deus é a salvação universal, como vimos, e se Deus não conhece limites outros que a liberdade humana que ele mesmo quis como tal, então deve obrigatoriamente haver a possibilidade de que todos os seres humanos se salvem, dentro ou fora do cristianismo. Rahner afirma que aqueles que não aderem a Cristo explicitamente e não pertencem institucionalmente à Igreja Católica são, na verdade, "cristãos anônimos".

Este conceito parece inspirar-se nas "sementes do Verbo", que, segundo Justino de Roma, do século II, estavam presentes já na filosofia grega, e que preparam as culturas para receber a verdade do cristianismo. Mas Rahner vai muito além: para ele, não se trata de esperar que as "sementes do Verbo" germinem e se tornem também cultura cristá. De fato, pelo mistério da Encarnação, crê-se que Jesus é verdadeiramente o "mediador entre Deus e os seres humanos" (1Tm 2,5) e não apenas entre Deus e a

\footnotetext{
${ }^{23}$ Rahner, "Anonymous Christians" 6, 393-394.
} 
cristandade. A redenção acontece realmente pela entrega de Cristo na consumação de seu sacrifício por amor e na ressurreição que o eleva à condição de cabeça não somente da Igreja, mas da humanidade inteira.

Para Rahner, "a revelação expressamente crista se torna a afirmação explícita da revelação da graça que o ser humano sempre experimenta implicitamente nas profundidades de seu ser" ${ }^{24}$. Assim, Rahner acredita que, sem cair no relativismo em relação à unicidade da salvação por meio de Cristo, é possível afirmar que a salvação não está confinada nos limites da instituição católica ou do cristianismo. Mas com isso a Igreja não perde sua identidade nem sua importância. A Igreja é a tematização da presença salvífica da graça incriada no mundo a partir da encarnação: “...o cristão não é mais tanto alguém que possui a graça (como se fosse mais ou menos certo que este não fosse o caso dos não-cristãos), mas alguém no qual a graça deseja revelar-se historicamente" 25 .

Com esse argumento, Rahner propóe a solução para vários problemas teológicos que a Igreja passa a enfrentar com o advento da modernidade: (a) a justificaçáo pela fé e a importância das obras, tema que emergiu na Reforma protestante; (2) a liberdade religiosa e a necessidade implícita ou explícita da Igreja para se receber a salvação; (3) o diálogo ecumênico e inter-religioso; (4) a tarefa missionária da Igreja frente às culturas não-cristãs etc.

É justamente por causa desse insight que Karl Rahner é considerado um dos mais importantes teólogos do Vaticano II, que foi onde o catolicismo finalmente tornou oficial essa interpretação aberta e inclusivista do "Extra ecclesiam nulla salus".

É importante registrar algumas das críticas que esta teoria rahneriana do cristianismo anônimo recebeu por parte dos teólogos seus contemporâneos: enquanto os conservadores a atacam ainda hoje por, segundo eles, relativizar a necessidade de Cristo para a salvação, por outro lado, para Moltmann, por exemplo, Rahner praticamente identifica humanidade com cristianismo e natureza com graça, e tal postura, longe de ser favorável a uma antropologia ponderada, eleva-a à condição de totalitária e triunfalista, pois, no fim das contas, "ser um humano torna-se a universalização da particularidade de ser um cristão; e ser um cristão torna-se a particularização da universalidade de ser um humano" ${ }^{26}$, o que esvaziaria a validade de qualquer religiáo não-cristã buscar em si mesma a verdade da salvação.

${ }^{24}$ Ibid., 394.

${ }^{25}$ Rahner, Nature and Grace. Dilemmas in the Modern Church, 9.

${ }^{26}$ Vandervelde, "The Grammar of Grace. Karl Rahner as a Watershed in Contemporary Theology”, 453. 


\section{A fé que opera pelo amor}

De acordo com Rahner, se o terreno para a autocomunicação salvadora de Deus não é exclusivamente a Igreja católica, uma vez que a graça incriada é dada a todo ser humano independentemente de religião, então a graça criada que realiza a salvação não é tanto a primeira virtude teologal, a fé - como tematização da graça -, quanto a terceira virtude teologal, a caridade, que é o que atematicamente refere todas as coisas a Deus.

Rahner afirma que na Escritura existe uma extensa variedade de termos para expressar o todo da salvação. Não há apenas uma palavra que contenha todo o significado da resposta humana à graça sobrenatural, que possibilita a salvação. "Para São Paulo, por exemplo, a 'palavra de ordem' é 'fé'. [...]. A palavra-chave para tudo em São João não é fé, mas amor, enquanto os sinóticos substituem mesmo isso por 'conversão' (metanoia)" ${ }^{27}$. Assim sendo, em diferentes épocas, podem-se eleger palavras diversas para expressar esta mesma realidade.

Rahner defende que "o 'amor ao próximo' pode facilmente ser o radical que realmente move as pessoas e a palavra-chave para hoje" 28 . Pressupondo que o amor ao próximo já é amor a Deus atematizado ${ }^{29}$, sem necessidade de qualquer referência explícita, Rahner defende que "o amor teologal necessariamente e por sua própria natureza já integra e conserva a fé e a esperança dentro de si” ${ }^{30}$, isto é, o amor-caridade equivale à fé como exigência intrínseca da salvação ${ }^{31}$.

De fato, São Paulo afirma que "a fé opera pelo amor" $(\mathrm{Gl}$ 5,6) e chega a afirmar que "ainda que eu tivesse toda a fé, a ponto de transportar montanhas, se não tivesse o amor, eu nada seria" (1Cor 13,2). Ora, se a fé tem tal dependência do amor para ter validade salvífica, isso significa que o amor, de certa forma, é superior à fé ou pelo menos tem precedência em relação a ela. Portanto, seguindo o argumento de Rahner:

Onde quer que haja um compromisso absolutamente moral de um modo positivo no mundo e dentro da presente economia da salvação, ali também

\footnotetext{
${ }^{27}$ Rahner, "Reflections on the Unity of the Love of Neighbour and the Love of God" 6, 248.

${ }^{28}$ Ibid., 249.

29 “O explícito categorizado amor ao próximo é o ato primário do amor a Deus” (ibid., 247).

${ }^{30}$ Ibid., 241.

${ }^{31}$ Neste mesmo sentido, Ratzinger escrevia, em 1968: "A nova aliança dá duas respostas à questão: do que o ser humano precisa para ser salvo? As duas respostas formam apenas uma numa aparente contradição. Elas simultaneamente afirmam que apenas o amor é necessário e que apenas a fé é necessária. Ambos, porém, expressam a mesma disposição de superação de si mesmo, pela qual o ser humano começa a abandonar seu próprio egoísmo e mover-se ao seu próximo. É por isso que seu irmão, seu companheiro, é a verdadeira pedra de toque dessa disposição. No 'tu' do irmão, o 'Tu' de Deus permanece incógnito ao ser humano" (Ratzinger, "Necessità della missione della Chiesa nel mondo", 72-73).
} 
existe um evento salvífico, fé, esperança e caridade, um ato da graça divinizante e, assim, a caritas é exercitada nele. [...]. Há uma possível distinção lógica, mas não real, entre um ato moral e um ato salvífico.32

Como se percebe, para Rahner, o amor é a linguagem da graça, a forma plena de correspondência à graça incriada. De fato, "o amor vem de Deus e todo aquele que ama nasceu de Deus e conhece a Deus. Aquele que não ama não conheceu a Deus porque Deus é amor" (1Jo 4,7-8). Nessa afirmação, São João não faz referência a uma exigência a mais do que o próprio amor para se conhecer a Deus. $\mathrm{O}$ amor possui em si mesmo todo o necessário para que o ser humano experimente a salvação, como já diz o antigo hino entoado na Quinta-feira Santa, ubi caritas et amor, Deus ibi est.

\section{Implicações no ecumenismo e diálogo inter-religioso}

Essa ideia de Rahner sobre a relação entre a natureza e a graça, que foi de certa forma adotada pelo Concílio Vaticano II, tem implicaçóes diretas no apostolado da Igreja, bem como na relação dos fiéis católicos com os não-católicos. Isso muda completamente a postura dos cristáos em relação aos que antes eram chamados "pagãos" e pelos rahnerianos são considerados "cristãos anônimos". Rahner diz que "quando [o batizado] encontra no mundo lei, ordem, amor, fidelidade, coragem, conforto na vida e força que enfrenta a morte, então ele sabe que ali a graça de Cristo está agindo”33. Em que sentido, então, se deve pensar a chamada nova evangelização?

Como já vimos, Rahner náo despreza a doutrina da necessidade de Cristo no processo da salvação do mundo. Mas ao interpretar essa necessidade como não necessariamente explícita, ele propóe um reposicionamento da missão evangelizadora. A relação entre Deus e o ser humano "é basicamente a mesma para todos os seres humanos, pois apoia-se na encarnação, morte e ressurreição do único Verbo de Deus feito carne" ${ }^{34}$. Há uma atitude muito mais otimista e aberta em relação às outras culturas e religiôes. E mais: de acordo com Rahner, não é necessária nem mesmo a pertença a alguma outra religião para que a salvação aconteça. $\mathrm{O}$ amor, encarnado na justiça, na paz, na solidariedade e compaixão pelos que sofrem, no respeito pela vida etc. é suficiente:

O ser humano, como ele realmente é, pode viver sua relação com Deus apenas na sociedade [...] e deve ter o direito e, de fato, o dever de viver essa relação com

\footnotetext{
${ }^{32}$ Ibid., 239.

${ }^{33}$ Rahner, Nature and Grace. Dilemmas in the Modern Church, 100.

${ }^{34}$ Rahner, "Christianity and the Non-Christian Religions" 5, 118.
} 
Deus dentro das realidades religiosas e sociais oferecidas a ele em sua particular situação histórica. ${ }^{35}$

Logo, evangelização não se identifica pura e simplesmente com proselitismo. Evangelizar significa primeiramente suscitar este amor teologal nas pessoas e sociedades mediante o testemunho do Evangelho. E a Igreja deve fazer isso por meio de duas atitudes fundamentais que devem anteceder o anúncio explícito de Jesus Cristo: o serviço e o diálogo. "A graça também existe fora da Igreja e seus sacramentos" ${ }^{36}$. Essa notícia deve nos dar alívio e alegria ao invés de nos fazer sentir ameaçados em nossa convicção de fé.

Uma consequência saudável desta descoberta para nós cristãos deve ser a mudança de foco pastoral, do fazer para o ser. Hoje, não faria o menor sentido, por exemplo, um missionário católico num território pagão imitar São Francisco Xavier em sua ânsia de salvar almas e, por isso, pondo-se a batizar milhares de pessoas num único dia, a ponto de isso provocar-lhe no braço "lesão por esforço repetitivo"... Ao invés disso, faria muito mais sentido que esse missionário católico procurasse "ser" uma presença solidária e fraterna de discípulo de Jesus no meio daquela sociedade, servindo com caridade e dialogando com tolerância.

\section{Graça e predestinação}

Karl Rahner, a partir de sua visão da relação entre natureza e graça, resume assim as consequências tiradas desta reflexão:

Toda a vida espiritual do ser humano é constantemente afetada pela graça. Ela não é um evento raro e episódico, até por ser imerecida. A teologia, por muito tempo e com frequência, foi atormentada pela inadmitida suposição de que a graça não seria mais graça se fosse distribuída por demais generosamente pelo amor de Deus! Toda a nossa vida espiritual é vivida no âmbito da vontade salvífica de Deus, de sua graça preveniente, de seu chamado a que esta se torne eficaz [...]. O ser humano, mesmo quando não o "conhece" e não crê nele [...], sempre vive conscientemente na presença de Deus [...]. Quando o ser humano é chamado pela mensagem de fé anunciada pela Igreja visível, esta não é a primeira vez que ele entra em contato espiritual com a realidade pregada pela Igreja: tal conhecimento conceitual dela vem primeiro. $\mathrm{O}$ chamado apenas o torna consciente $\mathrm{da}$ - e obviamente o obriga a fazer uma escolha sobre - a graça que já o abrange inarticulada mas realmente como um elemento de sua existência espiritual. [...]. A pregação é o expresso despertar do que já está presente no profundo do ser humano, não por natureza, mas por graça. Mas é uma graça

\footnotetext{
${ }^{35}$ Ibid. 5, 131.

${ }^{36}$ Rahner, "Nature and Grace" 4, 179.
} 
que sempre circunda o ser humano, mesmo o pecador e o descrente, como o cenário inescapável de sua existência. ${ }^{37}$

O conceito teológico de graça desenvolvido por Karl Rahner apresenta-a como um existencial sobrenatural que se relaciona com a natureza humana de tal modo que nem é idêntica a ela como um elemento inato a priori e nem se sobrepóe a ela como outra camada a posteriori. Pedindo vênia ao pensamento tomasiano, de que o próprio Rahner se considera herdeiro, um conceito caro à tradição escotiana é que pode aqui particularmente auxiliar-nos na compreensão dessa realidade a que nos referimos: a doutrina que o franciscano João Duns Scotus (1266-1308) desenvolveu a respeito da predestinação de Cristo à suma graça e de Maria à Imaculada conceição.

Segundo Scotus, independentemente do pecado humano que viria a se dar na história, Deus, eternamente, fora de qualquer determinação externa à sua própria vontade, em vista de ter fora de si um perfeito co-amante (condiligente) com quem dividir os tesouros da infinita caridade, determina a criação da natureza humana em vista do aparecimento do homem Jesus, a quem predestina à suma graça da união hipostática com o seu Verbo ${ }^{38}$, dando-lhe o primado absoluto entre as criaturas e tornando-o mediador perfeito de toda a criação, que foi feita também predestinada, nele, à suma glória.

O primado universal de Cristo passou a ser oficialmente reconhecido pela liturgia da Igreja na solenidade de Nosso Senhor Jesus Cristo, rei do universo, no último domingo do Tempo Comum, criada por decreto de Pio XI em 1925, em comemoração aos 1600 anos do Concílio de Niceia.

Ainda na teologia de Scotus, em vista desta união hipostática e pelos méritos desse mediador perfeito, Deus predestinou Maria a ser redimida pelo ato mais excelente da redenção, que é a preservação do pecado original, antes que a remissão deste $^{39}$. Tal opiniáo escotiana, tendo vencido definitivamente o longo debate teológico

${ }^{37}$ Ibid. 4, 180-181.

38 "Qui enim primo se amat ordinate (et per consequens non inordinate, zelando vel invidendo), secundo vult alios habere condiligentes, et hoc est velle alios habere amorem suum in se - et hoc est praedestinare eos, si velit eos habere huiusmodi bonum finaliter et aeternaliter; tertio autem vult illa quae sunt necessaria ad attingendum hunc finem, scilicet bona gratiae; quarto vult - propter ista - alia quae sunt remotiora" (Scotus, "Ordinatio" III, d. 32, q. un., n. 21) - "Aquele que, em primeiro lugar, ama-se a si mesmo ordenadamente (e, por consequência, não desordenadamente, isto é, por inveja ou malícia), em segundo lugar quer ter outros condiligentes [i.e., co-amantes], sendo isto querer [Deus] que outros tenham em si o seu amor, - e sendo isto predestiná-los, se quer que estes tenham tal bem finalmente e eternamente; em terceiro lugar, também quer aquelas coisas que são necessárias para atingir este fim, a saber, os bens da graça; em quarto lugar, quer - por causa disso - aqueles que são mais remotos".

39 "Perfectissimus enim mediator perfectissimum actum habet mediandi possibilem respectu alicuius personae pro qua mediatur, - ergo Christus habuit perfectissimum gradum mediandi possibilem respectu 
a respeito da possibilidade deste privilégio mariano, foi assumido oficialmente pela Igreja na proclamação do dogma da Imaculada conceição de Maria, em 1854, por Pio IX, que, no decreto Ineffabilis Deus, define que no primeiro instante da concepção, Maria recebeu a graça da justificação antecipadamente e em vista dos méritos de seu Filho, o que a preservou imune do pecado original e foi a condição de possibilidade da santidade perfeita de Maria em função de sua maternidade divina.

Ora, apenas a título de ilustração, vale observar que o mistério que Scotus considera ser a predestinação de Cristo equivale ao que Rahner chama de concessão da graça incriada, a não-repugnância que a natureza humana tem a ser assumida e personalizada por uma pessoa divina, razão pela qual o Verbo encarnado não precisa de redenção, por ser ele mesmo a própria redenção em pessoa. O próprio Rahner faz uma analogia entre a predestinação exclusiva de Cristo e a de todos os outros seres humanos:

A graça em todos nós e a união hipostática somente em Jesus Cristo, ambas só se podem pensar conjuntamente e significam na sua unidade uma única e livre decisão de Deus de estabelecer a ordem da salvação sobrenatural, de comunicar-se a si próprio. ${ }^{40}$

A argumentação escotiana de defesa da Imaculada conceição, por sua vez, ajudanos a compreender a distinção rahneriana entre natureza e graça: depois da criação de Maria, embora no primeiro instante (o que garante que Maria é total e simplesmente humana), porém antes do exercício de sua liberdade (o que garante que sua santidade perfeita é obra divina e não mérito seu), ela foi redimida. Ou seja, juntamente com a "graça incriada" comum a toda a humanidade, Deus infundiu também em Maria a "graça criada" que é a redenção, em função de sua especial condição de mater Dei. Esse privilégio concedido a Maria revela que todos os seres humanos já têm, pela graça incriada, a condiçáo de possibilidade de receber a graça criada em sua plenitude, que é a glória da visão beatífica.

Mas isso não quer dizer que os seres humanos sejam salvos automaticamente, pois exige-se uma resposta humana à graça, que só pode se dar na liberdade, o que

alicuius personae respectu cuius erat mediator; respectu nullius personae habuit excellentiorem gradum quam respectu Mariae; ergo etc. Sed hoc non esset nisi meruisset eam praeservare a peccato originali" (Scotus, "Ordinatio" III, d. 3, q. 1, n. 17-18) - "O mediador mais perfeito tem o ato de mediação mais perfeito para com aquela pessoa por quem media - portanto, Cristo teve o mais perfeito grau de mediação para com aquela pessoa para quem foi mediador; para com nenhuma pessoa ele teve um grau mais excelente do que para com Maria; portanto etc. Mas isso não aconteceria a não ser que ele merecesse para ela o preservar-se do pecado original".

${ }^{40}$ Rahner, Curso fundamental da fé. Introdução ao conceito de cristianismo, 242. 
significa que essa resposta é da ordem da vontade. Visto que o amor é um ato da vontade e a fé é um ato da inteligência, então, a salvação, segundo Rahner, não depende tanto da fé explícita como do amor-caridade. E este já é outro ponto em que Rahner acaba sendo mais escotista que tomista, visto que Scotus se contrapóe a Tomás ao defender a primazia da vontade sobre o intelecto.

Ao comentar a afirmação conciliar de que a Igreja é o "sacramento universal da salvação" ( $L G$ 48), Rahner observa que "um sinal nunca é simplesmente idêntico àquilo que significa. Portanto, sendo a Igreja o sinal sacramental da salvação do mundo, sabemos que a salvação se estende muito além dela" ${ }^{11}$. E “a incorporação de uma pessoa pelo batismo na Igreja visível é, antes de tudo, a continuação deste sinal de salvação no tempo e na história para as pessoas que não são membros da Igreja de um modo visível” ‘2. O desejo explícito - e realizado - do batismo por parte dos que entram visivelmente na Igreja é a tematização da salvação disponível a todos, mesmo aos que fazem experiência apenas atemática daquela graça que é, na condição humana, um existencial sobrenatural.

"Segundo Rahner, o decisivo para a salvação não é a sua consciência, pois

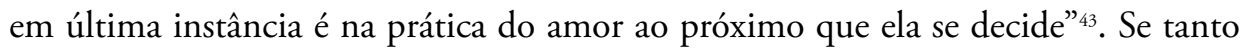
o desejo implícito de pertencer à Igreja quanto o amor ao próximo fazem as vezes da virtude teologal da fé, é possível afirmar que tal desejo, necessário e suficiente à salvação, corresponde à experiência da graça incriada como transcendental humano. Contudo, Rahner dá um passo a mais em relação aos teólogos que consideravam as religiôes não-cristãs como não mais que "preparação" para se receber o cristianismo; cuidadosamente, "Rahner explicita em vários momentos a presença nas religióes de 'traços sobrenaturais da graça,' de sua autêntica legitimidade e de sua positividade salvífica”"

Afinal, se a Igreja, sendo sinal, não passa de expressão de algo muito além de si mesma, a correspondência atemática à graça também já é um sinal mediador da salvação.

\section{Conclusão}

A Igreja Católica romana vive tempos desafiadores, de extremismos e intolerâncias. Nunca antes a rotulação de "direita" e "esquerda" foi tão marcada por polarizaçóes e

\footnotetext{
${ }^{41}$ Rahner, "The Future of Christian Communities" 22, 123.

${ }^{42}$ Rahner, "The Church and Atheism" 21, 143.

${ }^{43}$ Teixeira, "Karl Rahner e as religióes," 253-254.

${ }^{44}$ Ibid., 253.
} 
fechamentos ao diálogo. E desta vez, o próprio Romano Pontífice, o papa Francisco, tem sido veementemente acusado, por forças conservadoras do catolicismo, de ser "esquerdista”, "comunista", "relativista”. Por isso, faz-se pertinente revisitar esses conceitos aqui tratados, tão óbvios no pós-concílio Vaticano II, mas talvez não tanto neste período da história em que estamos. A relação entre natureza e graça está entre os principais pressupostos de tudo o que o papa Francisco tem escrito.

Jesuíta como Rahner, Bergoglio, embora sendo o primeiro papa desde o Vaticano II que dele não participou, viveu a partir de dentro o período inicial de implantação do Concílio na América Latina, tempo que coincidiu com o dos terríveis regimes militares no subcontinente, quando a Igreja se dividia entre dar suporte a revolucionários e apoiar regimes antissocialistas. Na "gangorra" da história, os países latino-americanos superaram as ditaduras, foram-se abrindo a projetos mais ou menos comprometidos com uma certa social democracia e, nos últimos anos, acenam para um certo retrocesso a propostas políticas mais conservadoras.

O mesmo movimento tem acontecido na teologia e na pastoral: muitos jovens cristáos de hoje parecem sentir saudades desse tempo que não viveram. É comum ver idosos com mentalidade mais aberta e progressista do que muitos jovens.

A teologia católica tem, como uma de suas marcas mais características, uma abertura universal ao diverso. A Igreja cristá já nasceu do processo de inclusão dos "pagãos" ao povo eleito, da ampliação do Israel de Deus. Desde seus inícios, o catolicismo olha sem medo para expressóes diferentes do sagrado, tomando-lhe elementos aqui e acolá, sem receio de contaminar-se ou de perder a própria identidade. É no mínimo estranha à catolicidade da Igreja uma postura hostil ao diferente por parte de seus membros, já que alteridade em comunhão é o que constitui a razão mesma de ser da Igreja.

O fato é que ser católico, não obstante tentativas mais ou menos oficiais ao longo da história, nunca foi, na prática, condizente com uniformizaçóes, visto que, em toda a extensão do rebanho da Igreja, há divergências maiores entre ovelhas e ovelhas do mesmo redil do que entre algumas ovelhas e certos bodes. E não é difícil comprovar que esse aspecto da Igreja já era conhecido - se não querido - pelo seu próprio fundador, aquele que quis fazer caberem na mesma comunidade o zelota Simão e o publicano Levi, e comerem da mesma mesa o pescador Simão e o notável Nicodemos, e testemunharem a mesma fé o essênio João e o fariseu Saulo; e isso até chegar aos nossos dias.

Uma instituição que consegue abrigar sob o mesmo teto uns jovens com botas de cruzados medievais de um lado e outros com Che Guevara estampado na camiseta do outro é ou não é um ousado ensaio da unidade esperada para o Reino escatológico? 
Afinal, se a graça não destrói a natureza e se a natureza humana é tão marcada pela história e seus conflitos, como será possível acontecer em realidade o profetizado pela metáfora do "banquete celeste" no qual tantas diferenças estejam em perfeita harmonia? Só mesmo se a graça acolher a natureza como ela é. Então, ou isso começa a ser aqui e agora, ou nunca será.

Um agente de pastoral que olha para as realidades seculares e não consegue reconhecer nelas qualquer traço do Evangelho de Jesus pode, com esta postura, estar sendo um funcionário exemplar de uma multinacional religiosa e mesmo um proselitista eficaz, mas não um discípulo no Nazareno. A fé genuinamente cristã não se sente incitada ao combate e nem sofre complexos de baixa autoestima quando vê o projeto de Cristo realizado in natura, prescindindo de roupagem religiosa.

Ao contrário, a fé cristã leva embutida em si uma alegria engatilhada para sorrir quando consegue enxergar sua própria imagem nos espelhos da esperança e da caridade que perambulam pela terra.

\section{Referências bibliográficas}

Coffey, David. “The Whole Rahner on the Supernatural Existential." Theological Studies 65 (2004): 95-118.

Denzinger, Heinrich; Hünermann, Peter. Compêndio dos símbolos, definiçōes e declaraçōes de fé e moral (2.ed.). São Paulo: Loyola-Paulinas, 2013.

Duffy, Stephen J. "Experience of Grace." En The Cambridge Companion to Karl Rahner, por D. Marmion y M. E. Hines, 43-62. Cambridge (U. K.)-New York (NY): Cambridge University Press, 2005.

Pio XII. "Carta encíclica Humani generis" (1950), Santa Sé, http://w2.vatican. va/ content/pius-xii/pt/encyclicals/documents/hf_p-xii_enc_12081950_humani-generis.html (consultado el 13 de abril de 2018).

Rahner, Karl. "Anonymous Christians". En Theological Investigations, por K. Rahner, Vol. 6, 390-398. Baltimore (MD): Helicon Press, 1969.

. "Christianity and the Non-Christian Religions". En Theological Investigations, por K. Rahner, Vol. 5, 115-134. Baltimore (MD): Helicon Press, 1966.

. "Concerning the Relationship between Nature and Grace". En Theological Investigations, por K. Rahner, Vol. 1, 297-317. Baltimore (MD): Helicon Press, 1961.

. Curso fundamental da fé. Introdução ao conceito de cristianismo (4. ${ }^{a}$ ed.). São Paulo: Paulus, 2008. 
. "Nature and Grace". En Theological Investigations, por K. Rahner, Vol. 4, 165-188. Baltimore (MD): Helicon Press, 1966.

. Nature and Grace. Dilemmas in the Modern Church. New York (NY): Sheed and Ward, 1964.

. "Reflections on the Experience of Grace". En Theological Investigations, por K. Rahner, Vol. 3, 86-90. Baltimore (MD): Helicon Press, 1967.

. "Reflections on the Unity of the Love of Neighbour and the Love of God". En Theological Investigations, por K. Rahner, Vol. 6, 231-249. Baltimore (MD): Helicon Press, 1969.

. "The Church and Atheism". En Theological Investigations, por K. Rahner, Vol. 21, 137-150. New York (NY): Crossroad, 1988.

. "The Future of Christian Communities". En Theological Investigations, por K. Rahner, Vol. 22, 120-133. New York (NY): Crossroad, 1991.

Ratzinger, Joseph. "Necessita della missione della Chiesa nel mondo". En La fine della Chiesa come societa perfetta, por M. Cuminetti y F. V. Joannes, 65-77. Verona: Mondadori, 1968.

Scotus, Ioannes Duns. "Ordinatio". In Opera omnia. Vols. 9-10. Roma: Typis Polyglottis Vaticanae, 2006-2007.

Teixeira, Faustino. "Karl Rahner e as religiōes". En Karl Rahner em perspectiva, organizado por Pedro Rubens F. de Oliveira y Claudio Paul, 243-262. São Paulo: Loyola, 2004.

Vandervelde, George. "The Grammar of Grace. Karl Rahner as a Watershed in Contemporary Theology". Theological Studies 49 (1988): 445-459.

Wandinger, Nikolaus. "Karl Rahner on Nature and Grace. A Journey through His Early Articles". http://www.uibk.ac.at/theol/leseraum/texte/341.html (consultado el 11 de abril de 2018). 